EMBRYARIDDLE
Aeronautical University

SCHOLARLY COMMONS
International Journal of Aviation, Aeronautics, and Aerospace

\title{
Preliminary Results of a Study Investigating Aviation Student's Intentions to use Virtual Reality for Flight Training
}

\author{
Stephanie G. Fussell \\ Kent State University, sfussel2@kent.edu \\ Dothang Truong \\ Embry-Riddle Aeronautical University, truongd@erau.edu
}

Follow this and additional works at: https://commons.erau.edu/ijaaa

Part of the Educational Technology Commons, and the Higher Education Commons

\section{Scholarly Commons Citation}

Fussell, S. G., \& Truong, D. (2020). Preliminary Results of a Study Investigating Aviation Student's Intentions to use Virtual Reality for Flight Training. International Journal of Aviation, Aeronautics, and Aerospace, 7(3). https://doi.org/10.15394/ijaaa.2020.1504

This Article is brought to you for free and open access by the Journals at Scholarly Commons. It has been accepted for inclusion in International Journal of Aviation, Aeronautics, and Aerospace by an authorized administrator of Scholarly Commons. For more information, please contact commons@erau.edu. 


\section{Introduction}

Educators and trainers in aviation environments utilize a variety of simulation technologies to promote high-fidelity, low-cost resources (Macchiarella, Arban, \& Doherty, 2006; Macchiarella, Brady, \& Lyon, 2008). These range in immersion and include basic and advanced aviation training devices, flight training devices, and full-flight simulators. These devices offer students the opportunity to train on iterative maneuvers and procedures without the cost and wear and tear associated with training on actual aircraft. Those skills and attitudes can transfer from the simulator to the real aircraft, as has been demonstrated by numerous transfer of training studies (Macchiarella et al., 2006; Rogers, Boquet, Howell, \& DeJohn, 2010; Taylor, Talleur, Emanuel, \& Rantanen, 2005). Immersive simulation technology that goes beyond traditional aviation simulation devices, such as augmented reality and virtual reality (VR), is the next step in enhancing aviation training. Anecdotal and empirical evidence show that incorporating technology in the classroom can enhance motivation, psychomotor skills, and knowledge (Sitzmann, 2011).

However, these technologies must enhance cognitive experiences if they are to be utilized effectively. Eastgate, Wilson, and D'Cruz (2015) noted that VE design should motivate users to attain goals in a safe and cost-efficient environment. These considerations are especially true if the technology is to be utilized in aviation training. As VR is developed for aviation training, the 
technology must be examined to ensure users are meeting learning objectives and transfer of training standards - similar to the rigorous research that preceded the incorporation of aviation training devices. One important consideration is the factors that influence a student to adopt new technology. The recent and incoming generations of students have utilized technology from an early age, making them highly adept at incorporating technology into several aspects of their lives (Eckleberry-Hunt, Lick, \& Hunt, 2018). This has driven educational and training institutions to incorporate immersive simulation technology, such as VR, into the training curriculum. Yet, the factors that influence a student to utilize immersive simulation technology for training/educational purposes have received little research. Indeed, the cost and time savings associated with using VR as opposed to a simulator have not been quantified; this may influence a student to use VR for training.

\section{Purpose of the Research}

The purpose of this research was to identify, validate, and confirm impact factors relevant to VR use in aviation training as well as flight training in general. The factors were identified based on established factors in the Technology Acceptance Model (TAM) literature and from the relevant research studies that explored aviation environments and VR technology. The chosen factors are unique for analyzing the use of VR technology in an aviation training environment. The factors are attitude towards use (ATU), behavioral intention 
(BI), perceived behavioral control (PBC), perceived enjoyment (PENJ), performance expectancy (PEXP), perceived ease of use (PEU), perceived health risk (PHR), perceived usefulness (PU), regulatory uncertainty (RU), and selfefficacy (SE). The operational definitions for the factors may be found in the Appendix.

The following research questions were investigated:

- What factors are relevant to understanding aviation students' intentions to use VR technology for flight training?

- How reliable and valid are the identified factors?

This study was a pilot study, which was utilized to test the reliability and validity of the measurement instrument. The validated instrument can be used to develop and test a full structural model that explains flight students' acceptance of VR in a flight training environment as well as their intent to use the technology. This research will contribute to the bodies of knowledge encompassing aviation training, VR in education, and VR in aviation training.

\section{Review of the Literature}

\section{VR in Education and Aviation Training}

Learning complex tasks in dynamic environments can be difficult for students. Gegenfurtner, Quesada-Pallarès, and Knogler (2014) found that utilizing technology in the learning process encourages exploration, self-efficacy with the technology, and familiarity with the learning process. Jensen and Kondrasen 
(2018) note that although VR is not appropriate for all tasks, it is beneficial for training on repetitive tasks to positively enhance visual-spatial skills, psychomotor skills, cognition, memory, and emotional responses. Jerald (2016) further explains that learning in a VE with VR encourages active learning and intuitive decision making, making it an ideal medium for scenario-based training. Although there is growing evidence that VR can enhance the educational environment, the research surrounding the student perspective of using this technology is often limited to subjective measures as opposed to objective.

Additionally, VR has received little research in aviation training environments despite its adoption in other dynamic learning environments. The extant literature surrounding this research reveals that most studies are confined to the development of training devices or VR programs for military pilots (Lewis \& Livingston, 2018; Palla, Brent, \& Sikorski, 2018). Research involving immersive simulation training in aviation has largely been limited to the transfer of training studies between aviation training devices and real aircraft (Macchiarella et al., 2006; Rogers, et al., 2010; Taylor et al., 2005).

\section{Theoretical Framework}

Davis, Bagozzi, and Warshaw (1989) created the TAM to explain how a user comes to accept and subsequently use a given technology. The model was developed for understanding the acceptance and adoption of information technology in the workplace and has since expanded for innovative technology in 
the classroom and other environments. The original model had four factors of PEU, PU, ATU, and BI.

The review of the literature informed the creation of the conceptual model of the pilot study as well as the theoretical framework surrounding aviation student's intention to use VR for flight training. The original relationships of the TAM (PEU impacts PU; PEU and PU influence ATU, and ATU impacts BI) are first discussed. Numerous studies have demonstrated that PEU and PU impact ATU, which positively influences BI; these relationships were confirmed for using e-learning technology in an educational environment (Cheung \& Vogel, 2013; Esteban-Millat, Martínez-López, Pujol-Jover, Gázquez-Abad, \& Alegret, 2018; Park, 2009) and VR in a consumer environment (Manis \& Choi, 2018). PEU was found to impact PU as well as ATU in educational and consumer contexts and with diverse technologies, including e-learning tools, check-in kiosks, and VR (Cheung \& Vogel, 2013; Esteban-Millat et al., 2018; Gong, Xu, \& Yu, 2004; Lu et al., 2008; Manis \& Choi, 2018). Wang, Anne, and Ropp (2016) found that PEU, PU, and ATU positively influence BI to use augmented reality -a less immersive simulation technology than VR- in an aviation education setting.

The TAM is often expanded to include additional factors that are appropriate for the environment and the technology being studied. These studies demonstrate the adaptability of the model across domains for a wide range of technologies. Lu et al. (2009) studied the use of check-in kiosks for airline 
services; they found that $\mathrm{BI}$ is also positively influenced by $\mathrm{PBC}$, which in turn is positively influenced by PEU. This finding was echoed by Venkatesh (2000) in a study exploring information technology in a commercial business setting.

Abdullah and Ward (2016) and Chang, Hajiyev, and Su (2017) found that PENJ influences PEU and PU toward using e-learning tools. PENJ was also found to influence perceived learning using VR (Makransky \& Lilleholt, 2018) as well as PU and ATU of VR for consumers (Manis and Choi, 2018). PEXP was found to impact the use of technology in education by Lewis, Fretwell, Ryan, and Parham (2013) and Onaolapo and Oyewole (2018). Shen et al. (2018) explored the use of VR in education and found that PEXP influences BI as well as use. PHR was found to impact PU, ATU, and the use of the internet for health care purposes (Ahadzadeh, Pahlevan Sharif, Ong, \& Khong, 2015). Myers (2019) investigated a similar factor, perceived risk, which negatively impacted ATU. RU was explored in consumer environments with the technologies of digital currency (Folkinshteyn \& Lennon, 2016) and mobile payment (Yang, Liu, Li, \& Yu, 2015); in both cases, RU was theorized to impact attitude and intention. Finally, SE was found to impact BI, PUE, and PU toward e-learning tools in an educational setting (Abdullah \& Ward, 2016; Cheung \& Vogel, 2013; Gong et al., 2004; Park, 2009); however, Lemay, Morin, Bazelais, and Doleck (2018) found that although SE impacted PEU, it did not impact PU in a simulation-based learning setting. 


\section{Gaps in the Research}

Although the TAM has been adopted for understanding user intention for a variety of technologies and environments, Wang et al. (2006) appear to be the only researchers to utilize a TAM to assess immersive simulation technology in an aviation education setting. The researchers used the original TAM to understand how students perceive the use of augmented reality in aviation maintenance training. However, they did not expand the TAM to include factors relevant to aviation training and augmented reality. There is little research that intersects the TAM, intention to use VR, and the aviation training environment. This is a gap in the literature in an industry that has embraced simulation technology for training since the early 20th century. As VR is developed for use in education, the factors that influence students to use VR and those which are detractors to use must be investigated.

\section{Methodology}

\section{Sample}

The sampling framework for the pilot study was aviation students enrolled at the Embry-Riddle Aeronautical University (ERAU), Daytona Beach campus ( $N$ $=1,636)$. Participants needed to be at least 18 years of age, actively enrolled, and currently flying with the program. The purpose of the pilot study was to test the validity and reliability of the survey instrument. A sample size of 42 aviation students was used for the pilot study. This sample size, which was greater than the 
recommended $10 \%$ of the target population (Connelly, 2008), was deemed sufficient for the pilot study.

\section{Data Collection Process}

Design and procedures. This study utilized a cross-sectional survey design. This design allows for the examination of a population at a definite point in time. Hair, Black, Babin, and Anderson (2010) note that a common approach to multivariate analysis is utilizing scales from prior research. Data collection occurred between the fall 2019 and spring 2020 semesters. An invitation to participate in the pilot study was sent to aviation students via email using a listserv. The questionnaire was developed using Google Forms. The questionnaire included an introduction with the purpose of the study, consent form, and a short video demonstrating the use of VR in a simulator (see Appendix).

Development of the CFA model. The conceptual framework of the model was created using 10 latent constructs, and 34 measurement items, each of which was written to support the validity of the constructs. The latent constructs were derived from the literature, although the constructs have been combined in new ways to reflect the context of the study. Figure 1 shows the CFA model that was tested. 


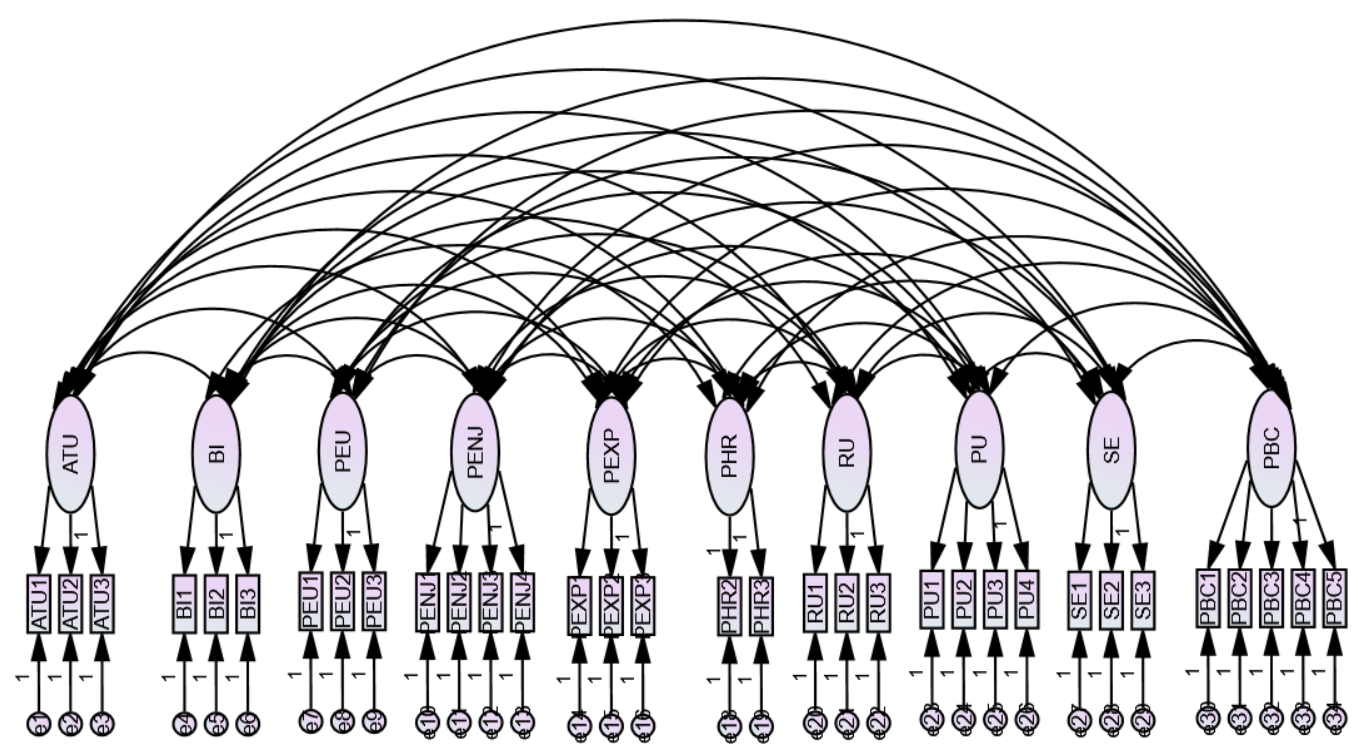

Figure 1. The CFA model.

\section{Measurement Instrument}

A structured questionnaire was designed using previously validated questions from published studies. Measurement items were adapted to reflect the latent constructs relevant to aviation, flight training, and VR technology. Likert response items were used to assess measurement items to determine the latent constructs that may influence aviation students' intentions to use VR technology for flight training, including attitude and behavioral intention. Participants responded to each item on a scale from 1 to 5 , where 1 was "strongly disagree," and 5 was "strongly agree." For the factor of PBC, participants rated their confidence level for a given statement, where 1 was "no confidence," and 5 was 
"total confidence." The ordering of the measurement was grouped by construct, enabling participants to easily follow the content in a logical manner. Within each construct grouping, the measurement items were shuffled to avoid potential issues with ordering effects. Demographic data were also collected in the questionnaire.

\section{Data Analysis Approach}

The data were prepared in SPSS and reviewed for missing values, outliers, and normality. A confirmatory factor analysis (CFA) model was created in AMOS to test the relationship of the measurement items to the latent constructs. Modification indices were also reviewed for potential relationships between error terms and cross-loading between an item and a factor. The reliability and validity of the questionnaire were thoroughly examined using SPSS and AMOS outputs.

Composite reliability was used to ensure the variables measure the factors they were intended to measure. A value greater than or equal to 0.7 was considered acceptable. Cronbach's alpha was also calculated in SPSS to test the reliability of the questionnaire items and the factors, with an acceptable value set at greater than or equal to 0.7 .

Construct validity was assessed during the pilot study to ensure the items measured the intended factor appropriately. Convergent validity tested the degree of relationship among items of a factor using average variance extracted (AVE). Factor loadings were assessed as they are a representation of regression weights in the model and can be used to assess convergent validity as well; an acceptable 
value was greater than or equal to 0.5 . Discriminant validity was analyzed by comparing the maximum shared variance (MSV) to the AVE of each factor to ensure the factors were distinct from each other. Fornell and Larcker (1981) state that if the $\mathrm{AVE}$ of a factor is greater than the MSV of corresponding factors, then discriminant validity is met.

\section{Results}

\section{Demographics and Descriptive Statistics}

Demographic data were collected to ensure the proper set up of the instrument. Six females (14.3\%) and 36 males (85.7\%) participated in the study, which aligns with the distribution of the program as a whole. Participants ranged in age from 18 to $37(M=20.60, S D=3.67) ; 40$ of the participants were undergraduate students, and two were graduate or beyond. The experience of the participants varied: 10 participants were student pilots, 25 had earned their private pilot license, 5 were commercial pilots, and 2 were certified flight instructors with advanced certificates. This range in experience was reflected in reported flight hours ( 0 to $430, M=148.01, S D=110.06$ ) and hours in an FTD ( 0 to $278, M=$ 41.85, $S D=45.77)$. A greater range in experience (i.e., education, certification, flight/FTD experience) is anticipated for the full study.

The items of each factor were grouped and analyzed, as shown in Table 1. The survey items were designed to be grouped by factors, hence the designation 
of "all." All of the factors had a mean between 3 ("neutral") and 4 ("agree" or "some confidence") except PHR, which was below neutral.

Table 1

Descriptive Statistics of the Factors

\begin{tabular}{lccccc}
\hline Factor & $\mathrm{N}$ & Mean & SD & Skewness & Kurtosis \\
\hline ATU_All & 42 & 3.76 & 1.21 & -0.74 & -0.13 \\
BI_All & 42 & 3.59 & 1.20 & -0.62 & -0.40 \\
PEU_All & 42 & 3.45 & 1.06 & -0.29 & -0.21 \\
PENJ_All & 42 & 3.88 & 1.00 & -0.78 & 0.37 \\
PEXP_All & 42 & 3.02 & 0.93 & -0.05 & -0.09 \\
PHR_All & 42 & 2.83 & 0.82 & -0.06 & -0.71 \\
RU_All & 42 & 3.07 & 1.01 & -0.15 & -0.16 \\
PU_All & 42 & 3.34 & 1.07 & -0.34 & -0.08 \\
SE_All & 42 & 3.58 & 1.03 & -0.50 & 0.21 \\
PBC_All & 42 & 3.44 & 1.05 & -0.25 & -0.68 \\
\hline
\end{tabular}

\section{CFA Results}

Model fit indices are sensitive to the sample size, so a lower threshold was used. The model fit values are shown in Table 2; the values were deemed marginal but accepted, as the purpose of the study was to validate the survey instrument and test the theoretical model. The low sample size was a known concern in running the CFA. Initially, the model was under-identified due to issues with items PHR1. Iterative testing revealed that removing the item was required and a regression weight was added to PHR2. A review of the kurtosis values indicated acceptable values below 3.0. Analysis of modification indices revealed a covariance arrow was needed between the error terms associated with 
PENJ1 and PENJ2. The issues with PHR1 and the error terms were noted for consideration during the analysis of the full study.

Table 3

Model Fit Indices of the Pilot Study

\begin{tabular}{|c|c|c|}
\hline Model Fit Index & Acceptance Value & Pilot Study Model \\
\hline$\overline{\mathrm{CFI}}$ & $\geq 0.93$ & 0.71 \\
\hline GFI & $\geq 0.90$ & 0.54 \\
\hline AGFI & $\geq 0.90$ & 0.43 \\
\hline NFI & $\geq 0.90$ & 0.56 \\
\hline CMIN/df & $\leq 3.00$ & 2.00 \\
\hline RMSEA & $\leq 0.06$ & 0.16 \\
\hline
\end{tabular}

Note. Small sample sizes make these values more sensitive and may indicate poor model fit. Acceptance values are taken from Hair et al. (2010).

\section{Construct Reliability and Validity}

The goal of the pilot study was to assess relationships within the CFA model and ensure the validity and reliability of the survey instrument. Before the dissemination of the questionnaire, Subject Matter Experts (SMEs) reviewed the measurement items for face validity, clarity, wording, and consistency among measurement items for a given construct.

The reliability assessment results of the pilot study revealed acceptable factor loading, composite reliability, Cronbach's alpha, and AVE values for the factors of ATU, BI, PBC, PENJ, PEU, PEXP, PU, SE, and RU, but not for PHR. The construct PHR had a low Cronbach's alpha (0.40) and factor loadings below 0.5. PHR1 was removed from the model to increase the reliability of the 
construct. A review of the modification indices suggested a covariance between the measurement items of PENJ1 and PENJ2 and the need for a regression weight addition to PEXP2. Table 3 details the results of the reliability assessments with low values highlighted. Table 4 details convergent and discriminant validity with potential issues highlighted. The results indicate that another measure may be required to assess discriminant validity in the full study.

Table 3

Reliability Assessment of the Pilot Study

\begin{tabular}{l|cccccccccc}
\multicolumn{1}{l}{ ATU } & BI & PBC & PENJ & PEU & PEXP & PHR & PU & RU & SE \\
\hline CR & 0.97 & 0.82 & 0.78 & 0.90 & 0.83 & 0.87 & $\mathbf{- 3 . 8 1}$ & 0.95 & 0.71 & 0.89 \\
CA & 0.98 & 0.89 & 0.85 & 0.93 & 0.87 & 0.86 & $\mathbf{0 . 5}$ & 0.96 & 0.76 & 0.9 \\
\hline
\end{tabular}
Note. $\mathrm{CA}=$ Cronbach's alpha. $\mathrm{CR}=$ Composite Reliability. Both values were ideally greater than or equal to 0.7 .

Table 4

Discriminant Validity Assessment of the Pilot Study

\begin{tabular}{ccccccccccc}
\hline & AVE & BI & PBC & PENJ & PEU & PEXP & PHR & PU & RU & SE \\
\hline ATU & 0.94 & $\mathbf{0 . 7 8}$ & 0.18 & 0.22 & $\mathbf{0 . 7 7}$ & 0.21 & 0.03 & 0.64 & 0.03 & 0.13 \\
BI & 0.75 & & 0.36 & 0.31 & $\mathbf{0 . 8 8}$ & 0.25 & 0.03 & $\mathbf{0 . 7 6}$ & 0.13 & 0.21 \\
PBC & 0.55 & & & 0.20 & 0.42 & 0.10 & 0.26 & 0.20 & 0.03 & 0.37 \\
PENJ & 0.76 & & & & 0.37 & 0.05 & 0.01 & 0.34 & 0.08 & 0.34 \\
PEU & 0.70 & & & & & 0.35 & 0.08 & $\mathbf{0 . 7 5}$ & 0.04 & 0.37 \\
PEXP & 0.72 & & & & & & 0.28 & 0.30 & 0.01 & 0.09 \\
PHR & 0.36 & & & & & & & 0.11 & 0.01 & 0.04 \\
PU & 0.85 & & & & & & & & 0.14 & 0.26 \\
RU & 0.52 & & & & & & & & & 0.03 \\
\hline
\end{tabular}

Note. AVE should be greater than or equal to 0.5. 


\section{Discussion}

The CFA of the pilot study was under-identified due to the low sample size and the low reliability of the PHR measurement items. These results provide direction for the analysis after the full study is completed in the spring of 2020. The revision of the PHR items was an important part of the process of creating and validating the survey instrument. The review and revision allowed for a shift in focus of the construct to physical health as opposed to possible health risks or physical harm in general. The full study will help determine if the wording change better aligned the items to the factor.

The results of the pilot study reveal strong relationships among the original TAM factors (ATU, BI, PEU, PU), which is consistent with the literature. If a user does not expect that using VR for flight training will require extra effort, or no more so than another immersive simulation technology, they may be more inclined to use it. Likewise, if a user believes that VR will benefit and enhance flight training, they may be more likely to use the technology. The factors of PHR and RU did not have strong relationships with ATU and BI. This indicates that participants may not be concerned about the health risks or regulatory concerns associated with VR, or they may lack familiarity with these issues. It is also possible that because they have familiarity with other immersive simulation devices, the participants did not consider the health risks to be an issue. More research is required, and it was determined that the wording of the PHR factor and 
its items to focus on health risks may have influenced the responses. Currently, VR is not utilized for flight training at ERAU, nor did the participants have a significant amount of experience with VR from which to draw from. Additionally, VR has yet to become available for flight training purposes and is not an approved device for flight training. As VR programs are developed for flight training and implemented into curriculum, aviation student perception may change. Given the lack of support in the literature, it will be interesting to see what is revealed after the full study is analyzed.

\section{Conclusions}

This pilot study demonstrated the reliability and validity of a survey instrument, which will be used for a full study to determine the factors that influence aviation students to use VR for flight training. The results of the pilot study informed the researchers on which factors and measurement items needed revision before mass distribution. The extended TAM created for the full study, which was validated in the pilot study, is the first of its kind to incorporate factors that influence the acceptance and use of immersive simulation technology, specifically VR, for flight training. The results of the pilot study provide preliminary insight into understanding the student perception of using VR and those factors that may detract from acceptance and, ultimately, using the technology. Pilot training at a flight school is a complex issue governed by the Federal Aviation Administration (FAA). As technology is developed for training 
aviation students, researchers must ensure not only that the technology meets learning objectives, but also that the technology is correctly incorporated into the training curriculum efficiently and effectively. Aviation students may not be comfortable using VR technology due to a lack of experience or may not perceive the benefits of using the technology for training. As such, developers and educators facilitate the acceptance of the VR for flight training.

\section{References}

Abdullah, F., \& Ward, R. (2016). Developing a general extended technology acceptance model for E-learning (GETAMEL) by analysing commonly used external factors. Computers in Human Behavior, 56, 238-256. doi:10.1016/j.chb.2015.11.036

Ahadzadeh, A. S., Pahlevan Sharif, S., Ong, F. S., \& Khong, K. W. (2015). Integrating health belief model and technology acceptance model: An investigation of health-related internet use. Journal of Medical Internet Research, 17(2), e45. doi:10.2196/jmir.3564

Ajzen, I., \& Fishbein, M. (1980). Understanding attitudes and predicting social behavior. Englewood Cliffs, NJ: Prentice-Hall.

Chang, C., Hajiyev, J., \& Su, C. (2017). Examining the students' behavioral intention to use elearning in Azerbaijan? The general extended technology acceptance model for Elearning approach. Computers \& Education, 111, 128-143. doi:10.1016/j.compedu.2017.04.010

Cheung, R., \& Vogel, D. (2013). Predicting user acceptance of collaborative technologies: An extension of the technology acceptance model for e-learning. Computers \& Education, $63,160-175$

Connelly, L. M. (2008). Pilot studies. Medsurg Nursing, 17(6), 411-412. 
International Journal of Aviation, Aeronautics, and Aerospace, Vol. 7 [2020], Iss. 3, Art. 2

Davis, F. D.; Bagozzi, R. P.; Warshaw, P. R. (1989). User acceptance of computer technology: A comparison of two theoretical models. Management Science, 35(8), 982-1003. doi:10.1287/mnsc.35.8.982

Eckleberry-Hunt, J., Lick, D., \& Hunt, R. (2018). Is medical education ready for Generation Z? Journal of Graduate Medical Education, 10(4), 378-381. Retrieved from https://www.jgme.org/doi/full/10.4300/JGME-D-18-00466.1

Esteban-Millat, I., Martínez-López, F. J., Pujol-Jover, M., Gázquez-Abad, J. C., \& Alegret, A. (2018). An extension of the technology acceptance model for online learning environments. Interactive Learning Environments, 26(7), 895-910, doi:10.1080/10494820.2017.1421560

Folkinshteyn, D. \& Lennon, M. (2016). Braving bitcoin: A technology acceptance model (TAM) analysis. Journal of Information Technology Case and Application Research, 18(4), 220249. doi:10.1080/15228053.2016.1275242

Fornell, C., \& Larcker, D.F. (1981). Evaluating structural equations with unobservable variables and measurement error. Journal of Marketing Research, 18(1), 39-50.

Gegenfurtner, A., Quesada-Pallarès, C., \& Knogler, M. (2014). Digital simulation-based training: A meta-analysis. British Journal of Educational Technology, 45(6), 1097-1114. doi:10.1111/bjet.12188Gong, M., Xu, Y., \& Yu, Y. (2004). An enhanced technology acceptance model for web-based learning. Journal of Information Systems Education, 15(4), 365 .

Hair, J. F., Black, W. C., Babin, B. J., \& Anderson, R. E. (2010). Multivariate data analysis. New Jersey: Pearson Prentice Hall.

Jensen, L., \& Konradsen, F. (2018). A review of the use of virtual reality head-mounted displays in education and training. Education and Information Technologies, 23(4), 1515-1529. doi:10.1007/s10639-017-9676-0 
Jerald, J. (2016). The VR book: Human-centered design for virtual reality. New York, NY: Association for Computing Machinery.

Lemay, D. J., Morin, M. M., Bazelais, P., \& Doleck, T. (2018). Modeling students' perceptions of simulation-based learning using the technology acceptance model. Clinical Simulation in Nursing, 20, 28-37. doi:10.1016/j.ecns.2018.04.004

Lewis, C. C., Fretwell, C. E., Ryan, J., \& Parham, J. B. (2013). Faculty use of established and emerging technologies in higher education: A unified theory of acceptance and use of technology perspective. International Journal of Higher Education, 2(2), 22-34.

Lewis, J., \& Livingston, J. (2018). Pilot Training Next: Breaking institutional paradigms using student-centered multimodal learning. Proceedings of Interservice/Industry Training, Simulation, and Education Conference (I/ITSEC) 2018, Orlando, FL.

Lu, J., Chou, H., \& Ling, P. (2009). Investigating passengers' intentions to use technology-based self check-in services. Transportation Research, Part E(45), 345-356. doi:10.1016/j.tre.2008.09.006

Macchiarella, N. D., Arban, P. K., \& Doherty, S. M. (2006). Transfer of training from flight training devices to flight for ab-initio pilots. International Journal of Applied Aviation Studies, 6(2). Retrieved from http://commons.erau.edu/publication/149

Macchiarella, N. D., Brady, T., \& Lyon, B. S. (2008). An application of high fidelity FTDs for ab initio pilot training: The way ahead. Collegiate Aviation Review, 26(1). https://doi.org/10.1109/dasc.2005.1563375

Makransky, G., \& Lilleholt, L. (2018). A structural equation modeling investigation of the emotional value of immersive virtual reality in education. Educational Technology Research and Development, 66(5), 1141-1164. doi:10.1007/s11423-018-9581-2

Manis, K. T. \& Choi, D. (2018). The virtual reality hardware acceptance model (VR-HAM): Extending and individuating the technology acceptance model (TAM) for virtual reality 
International Journal of Aviation, Aeronautics, and Aerospace, Vol. 7 [2020], Iss. 3, Art. 2

hardware. Journal of Business Research (in press). Retrieved from https://doi.org/10.1016/j.jbusres.2018.10.021

Myers, P. L. III. (2019). A behavioral research model for small unmanned aircraft systems for data gathering operations (Doctoral dissertation). Retrieved from https://commons.erau.edu/edt/449

Onaolapo, S., \& Oyewole, O. (2018). Performance expectancy, effort expectancy, and facilitating conditions as factors influencing smart phones use for mobile learning by postgraduate students of the University of Ibadan, Nigeria. Interdisciplinary Journal of e-Skills and Lifelong Learning, 14(1), 95-115.

Palla, A., Brent, L., \& Sikorski, E., (2018). Training with virtual reality: Lessons learned. In Proceedings of the Interservice/Industry Training, Simulation and Education Conference (I/ITSEC).

Pan, J. Y., \& Truong, D. (2018). Passengers' intentions to use low-cost carriers: An extended theory of planned behavior model. Journal of Air Transport Management, 69, 38-48. doi:10.1016/j.jairtraman.2018.01.006Park, S. Y. (2009). An analysis of the technology acceptance model in understanding university students' behavioral intention to use elearning. Educational Technology \& Society, 12(3), 150-162.

Rogers, R. O., Boquet, A., Howell, C., \& DeJohn, C. (2010). A two-group experiment to measure simulator-based upset recovery training transfer. International Journal of Applied Aviation Studies, 10(1), 153-168. FAA Academy. https://www.academy.jccbi.gov/ama800/Summer_2010.pdf

Shen, C., Ho, J., Ly, P. T. M., \& Kuo, T. (2018, May 18). Behavioural intentions of using virtual reality in learning: Perspectives of acceptance of information technology and learning style. Virtual Reality, 1-12. doi:10.1007/s10055-018-0348-1 
Sitzmann, T. (2011). A meta-analytic examination of the instructional effectiveness of computerbased simulation games. Personnel Psychology, 64(2), 489-528. https://doi.org/10.1111/j.1744-6570.2011.01190.x

Taylor, H. L., Talleur, D. A., Rantanen, E. M., \& Emanuel, T. W., Jr. (2004). The effectiveness of a personal computer aviation training device (PCATD), a flight training device (FTD), and an airplane in conducting instrument proficiency checks. Final Technical Report AHFD-04-12/FAA-04-05. Oklahoma City, OK: Federal Aviation Administration Civil Aerospace Medical Institute. Retrieved from http://www.tc.faa.gov/logistics/grants/pdf/2001/01-G-037\%20Volume\%201.pdf

Venkatesh, V. (2000). Determinants of perceived ease of use: Integrating control, intrinsic motivation, and emotion into the technology acceptance model. Information Systems Research, 11(4), 342-365.

Wang, Y., Anne, A., \& Ropp, T. (2016). Applying the technology acceptance model to understand aviation students' perceptions toward augmented reality maintenance training instruction. International Journal of Aviation, Aeronautics, and Aerospace, 3(4).https://doi.org/10.15394/ijaaa.2016.1144

Yang, Y., Liu, Y., Li, H., \& Yu, B. (2015). Understanding perceived risks in mobile payment acceptance. Industrial Management \& Data Systems, 115(2), 253-269.

doi:10.1108/IMDS-08-2014-0243 


\section{Appendix}

\section{Operational Definitions of the Factors and Associated Pilot Study Survey}

\section{Items}

\begin{tabular}{|c|c|c|c|}
\hline Factor & Definition & Variable Type & Reference \\
\hline $\begin{array}{l}\text { Attitude } \\
\text { toward use }\end{array}$ & $\begin{array}{l}\text { The degree to which } \\
\text { a student has a } \\
\text { favorable or } \\
\text { unfavorable appraisal } \\
\text { or evaluation of VR } \\
\text { for flight training. }\end{array}$ & $\begin{array}{l}\text {-Using VR for flight training is a } \\
\text { good idea. } \\
\text {-Using VR for flight training is a } \\
\text { wise idea. } \\
\text {-I feel positively toward using VR } \\
\text { for flight training. }\end{array}$ & $\begin{array}{l}\text { Esteban-Millat et } \\
\text { al., 2018; Gong } \\
\text { et al., 2004; Lee } \\
\text { et al., 2019; } \\
\text { Manis \& Choi, } \\
\text { 2018; Park 2009 }\end{array}$ \\
\hline $\begin{array}{l}\text { Behavioral } \\
\text { intention }\end{array}$ & $\begin{array}{l}\text { An indication of how } \\
\text { hard a student is } \\
\text { willing to try or how } \\
\text { much effort they are } \\
\text { planning to exert in } \\
\text { order to use VR for } \\
\text { flight training. }\end{array}$ & $\begin{array}{l}\text {-If made available, I am willing to } \\
\text { use VR for flight training. } \\
\text {-If made available, I intend to use } \\
\text { VR for flight training. } \\
\text {-If made available, I intend to use } \\
\text { every flight training lesson } \\
\text { provided through VR. }\end{array}$ & $\begin{array}{l}\text { Esteban-Millat et } \\
\text { al., 2018; Gong } \\
\text { et al., 2004; Lee } \\
\text { et al., 2019; } \\
\text { Manis \& Choi, } \\
\text { 2018; } \\
\text { Makransky \& } \\
\text { Lilleholt, 2018; } \\
\text { Shen et al. 2018 }\end{array}$ \\
\hline $\begin{array}{l}\text { Perceived } \\
\text { behavioral } \\
\text { control }\end{array}$ & $\begin{array}{l}\text { The extent to which } \\
\text { an aviation student } \\
\text { feels able to control } \\
\text { using VR technology } \\
\text { for flight training. }\end{array}$ & $\begin{array}{l}\text {-I could use VR technology for } \\
\text { flight training if no one was } \\
\text { around to tell me what to do (e.g., } \\
\text { a flight instructor or an assistant). } \\
\text {-I could use VR technology for } \\
\text { flight training if I had only the } \\
\text { manuals for reference. } \\
\text {-I could use VR technology for } \\
\text { flight training if I had only a } \\
\text { virtual instructor guiding me. } \\
\text {-I could use VR technology for } \\
\text { flight training if I could call } \\
\text { someone for help if I got stuck. } \\
\text {-I could use VR technology for } \\
\text { flight training if I had used similar } \\
\text { systems (e.g., an advanced } \\
\text { aviation training device, a flight } \\
\text { training device) previously. }\end{array}$ & $\begin{array}{l}\text { Chang et al., } \\
\text { 2018; Pan \& } \\
\text { Truong, } 2018\end{array}$ \\
\hline $\begin{array}{l}\text { Perceived } \\
\text { ease of use }\end{array}$ & $\begin{array}{l}\text { The degree to which } \\
\text { a student believes that } \\
\text { using VR for flight } \\
\text { training would be free } \\
\text { of effort. }\end{array}$ & $\begin{array}{l}\text { - Learning to use VR for flight } \\
\text { training will be easy for me. } \\
\text {-It will be easy to gain skills for } \\
\text { flight training using VR. } \\
\text {-Using VR for flight training will } \\
\text { make my flight training } \\
\text { progression easier. }\end{array}$ & $\begin{array}{l}\text { Esteban-Millat et } \\
\text { al., 2018; Gong } \\
\text { et al., 2004; Lee } \\
\text { et al., 2019; } \\
\text { Makransky \& } \\
\text { Lilleholt, 2018; } \\
\text { Manis \& Choi, } \\
\text { 2018; Park, }\end{array}$ \\
\hline
\end{tabular}




\begin{tabular}{|c|c|c|c|}
\hline Factor & Definition & Variable Type & Reference \\
\hline & & & $\begin{array}{l}\text { 2009; } \\
\text { Richardson } 2017\end{array}$ \\
\hline $\begin{array}{l}\text { Perceived } \\
\text { enjoyment }\end{array}$ & $\begin{array}{l}\text { The degree to which } \\
\text { using VR for flight } \\
\text { training is perceived } \\
\text { to be enjoyable in its } \\
\text { own right apart from } \\
\text { any performance } \\
\text { consequences that } \\
\text { may be anticipated. }\end{array}$ & $\begin{array}{l}\text {-Using VR for flight training } \\
\text { would be enjoyable. } \\
\text {-Using VR for flight training } \\
\text { would be exciting. } \\
\text {-I enjoy using immersive } \\
\text { simulation technology such as } \\
\text { VR. } \\
\text {-I have fun using immersive } \\
\text { simulation technology such as } \\
\text { VR. }\end{array}$ & $\begin{array}{l}\text { Chang et al., } \\
\text { 2018; Lee et al., } \\
\text { 2019; } \\
\text { Makransky \& } \\
\text { Lilleholt, 2018; } \\
\text { Manis \& Choi, } \\
2018\end{array}$ \\
\hline $\begin{array}{l}\text { Performance } \\
\text { expectancy }\end{array}$ & $\begin{array}{l}\text { The degree to which } \\
\text { a student believes that } \\
\text { using VR for flight } \\
\text { training will improve } \\
\text { flight performance as } \\
\text { compared to an FTD. }\end{array}$ & $\begin{array}{l}\text {-Using VR for flight training is } \\
\text { more productive than using a } \\
\text { flight training device. } \\
\text {-Using VR for flight training will } \\
\text { improve my flying skills more } \\
\text { efficiently than using a flight } \\
\text { training device. } \\
\text {-By expending the same effort as } \\
\text { in a flight training device, using } \\
\text { VR for flight training will } \\
\text { improve the progression of my } \\
\text { training. }\end{array}$ & $\begin{array}{l}\text { Onaolapo \& } \\
\text { Oyewole, 2018; } \\
\text { Shen et al., } 2017\end{array}$ \\
\hline $\begin{array}{l}\text { Perceived } \\
\text { health risk }\end{array}$ & $\begin{array}{l}\text { The perception a } \\
\text { student forms and } \\
\text { revises based on the } \\
\text { possible physical } \\
\text { health risks of using } \\
\text { VR for flight training. }\end{array}$ & $\begin{array}{l}\text {-Using VR for flight training may } \\
\text { negatively affect my physical } \\
\text { health. } \\
\text {-Using VR for flight training is } \\
\text { safer for me physically than using } \\
\text { a flight training device. } \\
\text {-Using VR for flight training is } \\
\text { safer for me physically than using } \\
\text { an actual aircraft. }\end{array}$ & $\begin{array}{l}\text { Ahadzadeh et al., } \\
\text { 2015; Myers, } \\
2019\end{array}$ \\
\hline $\begin{array}{l}\text { Perceived } \\
\text { usefulness }\end{array}$ & $\begin{array}{l}\text { The degree to which } \\
\text { a student believes that } \\
\text { using VR for flight } \\
\text { training would } \\
\text { enhance his or her } \\
\text { performance. }\end{array}$ & $\begin{array}{l}\text {-Flight training using VR will be } \\
\text { useful for flying in the real world. } \\
\text {-Using VR would enhance flight } \\
\text { training. } \\
\text {-Using VR would improve my } \\
\text { performance in flight training. } \\
\text {-Using VR would make flight } \\
\text { training more effective. }\end{array}$ & $\begin{array}{l}\text { Esteban-Millat et } \\
\text { al., 2018; Gong } \\
\text { et al., 2004; Lee } \\
\text { et al., 2019; } \\
\text { Manis \& Choi, } \\
\text { 2018; } \\
\text { Makransky \& } \\
\text { Lilleholt, 2018; } \\
\text { Park, 2009; } \\
\text { Richardson, } \\
2017\end{array}$ \\
\hline $\begin{array}{l}\text { Regulatory } \\
\text { uncertainty }\end{array}$ & $\begin{array}{l}\text { The degree to which } \\
\text { the lack of FAA } \\
\text { regulations regarding } \\
\text { the use of VR for } \\
\text { flight training }\end{array}$ & $\begin{array}{l}\text {-I am hesitant to use VR for flight } \\
\text { training because there are no FAA } \\
\text { regulations regarding its use. }\end{array}$ & $\begin{array}{l}\text { Folkinshteyn \& } \\
\text { Lennon, 2016; } \\
\text { Yang et al., 2015 }\end{array}$ \\
\hline
\end{tabular}




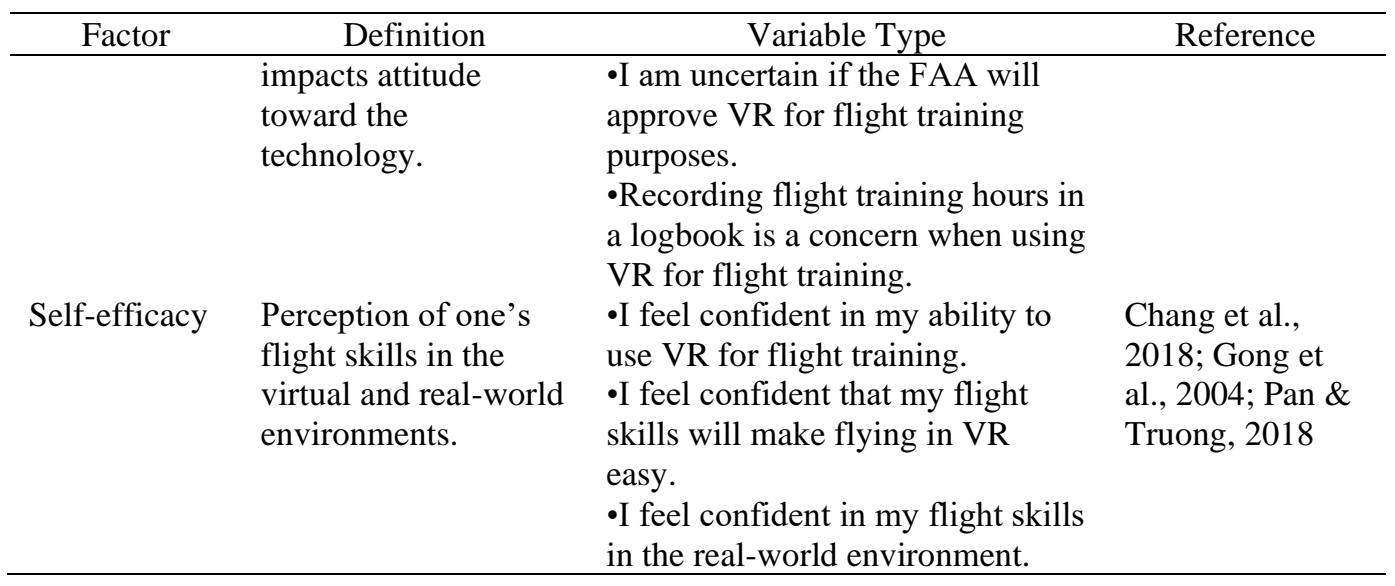

